\title{
2002 Frédéric Joliot/Otto Hahn Summer School in Reactor Physics
}

2002年 8 月20 30日 (CEA カダラッシュ研究所, フランス)

\begin{abstract}
京都大学 宇根嵭博信, 日本原子力研究所 小川 徹, FZK＼cjkstart鈴木 徹，日本原子力産業会議 向山武彦
\end{abstract}

Frédéric Joliot/Otto Hahn Summer School in Reactor Physics は1995年以 来, 毎夏開催されている原子炉物理学 の国際セミナーであり,フランス CEA とドイッ FZKの主催により, 今年度 は2002年 8 月21〜30日の日程でフラ ンス $\mathrm{CEA}$ カダラッシュ研究所にて開 催された。今年度は,「放射性廃裹物 の核変換処理および関連した革新的技 術」を主テーマとして，66名の参加の 下，22名の講師により，(1)放射性廃棄 物の核変換処理の動機と計画 $(7$ 時 間), (2)核変換処理の物理とシナリオ (4 時間), (3)加速器駆動未臨界システ ム (ADS) とその構成要素(13時間), (4)技術と材料：核変換処理に関連した 特定の問題(11時間)，(5)核デー夕( 5 時間)の各トピックについて講義が行 われた。

今年度の特徴は, 1 つの主テーマに 沿って, 炉物理以外の諸分野を含んだ 総合的なセミナーが開催されたことで ある。このため, 炉物理, 核デー夕, 熱水力・安全性, 燃料・材料, バック エンド工学等といった幅広いジャンル から, 若手研究者, ポスドク研究員, 博士課程学生といった若手に加え, ADSを巡るすべてについて学びたい という, 米国, ヨーロッパ, 中国の国 立研究所のグループリーダーや部長ク ラスの人々も含まれていたことも特徴 的であった。

\section{講義の概要}

本セミナーの基調講演シリーズであ るトピック 1 「放射性廃棄物の核変換 処理の動機と計画」では, まず, 原産 の向山が,「放射性廃棄物の核変換処 理の動機と計画」と題し, 本セミナー
の幕開けとして, 分離核変換 $(\mathrm{P} \& \mathrm{~T})$ の基本概念，世界の研究開発動向の概 要, P\&T サイクルと商用発電炉燃料 サイクルを分離して，それぞれの最適 化をめざした階層核燃料サイクル概念 を中心とした日本における研究開発状 況等について幅広く講義した。

LANL (米)の E. D. Arthur 氏 の「米 国における放射性廃棄物の核変換処理 の動機と計画」では, 米国における P \&T 関連研究の現状として，1990年以 前と，それ以降，特にAccelerator Transmutation of Waste (ATW) 計画 から Advanced Fuel Cycle Initiative (AFCI)にかけた近年の研究動向につ いて，米国固有の政治的背景の解説を 含めた講義が行われた。米国について は，P\&Tを，先進核燃料开イクルの 一環として，第 2 , 第 3 最終処分場の 建設の必要性を可能な限り減ずるため に必要な技術として積極的に検討して いきたい，という姿勢に変わってきた ことが特筆される。

$\mathrm{SCK}-\mathrm{CEN}$ (ベル ギー)の H. AitAbderrahim 氏の「ヨーロッパにおけ る ADS 計画：現在の設計案と展望」 では，ヨーロッパにおける ADS 関連 開発研究の現状, 特に, 実験用 ADS の概念設計プロジェクトである PDS -XADSについて講義が行われた。同 氏の「実験開発用多目的 ADS “MYRRHA”の概念設計」では，350 $\mathrm{MeV}$ サイクロトロンと $\mathrm{Pb}-\mathrm{Bi}$ 冷却炉 心を組み合わせた研究用 ADS である MYRRHA 炉の概念設計活動の紹介が 行われた。同炬は, 燃料 - 材料照射施 設としての機能と, ADS 実験炉とし ての機能を併せ持つものであり, ヨー ロッパ全体で盛んに研究開発が行われ
ていることが印象的であった。

トピック 2 「核変換処理の物理とシ ナリオ」では, CEA(仏)/ANL(米)の M. Salvatores 氏より「臨界および未臨 界炬における核変換処理の物理と燃料 サイクルに対するインパクト」, ANL のP.J. Finck 氏より「核変換システム の物理：システムの可能性とパフォー マンス」と題した講義があった。 Salvatores 氏はマイナーアクチニド (MA) および長寿命核分裂生成物を原 子炬に導入したときの炉物理特性を中 心に，燃料サイクルへのインパクト， 炬型の選択などについて解説し，P\& $\mathrm{T}$ システムの成立性にとって，然料开 イクルにおける回収率が重要なポイン トであることを指摘した。Finck 氏 は, 米国と日本・ヨーロッパの P\&T に対するアプローチの違いから始め, $\mathrm{MOX}$ 軽水炉，トリウム装荷炉，ガス 冷却炬による核変換特性を炉物理の観 点から概説した。

トピック 3 「加速器駆動システムと その構成要素」では, 加速器およびター ゲット技術に関して ANLの J.M. Carpenter 氏より「核破砕源に関する 経 験」, IPN Orsay(仏)の A. Müller 氏, Univ. of Milano(伊)の C. Pagani 氏より「高出力加速器」, CERN (スイ ス)のS.Buono 氏より「加速器駆動シ ステムにおけるビームターゲット設 計」と題した講義が行われ，核破砕源 の開発の歴史, 加速器の基礎理論から 最先端技術，空なしビームターゲット の流動試験および詳細設計が紹介され た。ADS用陽子加速器については, Müller, Pagani両氏ともに, 大電流 および安定性の観点から，これまでの 経験に基づくと最もふさわしい加速器 
はLINACであるとの見解を強調して いた。なお，Pagani氏の講義では， ビームトリップ頻度の改善状況が説明 されたが，続く質疑応答ではビームト リップのとらえ方に関する加速器サイ ドと原子炉サイドの立場の違いがはっ きりと現れていたことは興味深かっ た。

次に, ADSの炉物理に関して, CIEMAT(スペイン)の E. Gonzalez Romero 氏より「ADSの物理と物理実 験」, KTH Stockholm(スウェーデン) の P. Seltborg 氏より「未臨界炬と解析 ツール」と題した講義が行われた。 Seltborg氏の講義では, MASURCA 臨界集合体で行われている ADS 模擬 実験である MUSE 実験の解析結果が 紹介されたが, 同氏は博士課程の学生 で, 多くの参加者と同世代の講師とし て抜擢されたとのことである。

FRAMATOME (仏)の B. Carluec 氏より「未臨界炬の安全性」と題した講 義が行われ，一般論として臨界炉より 優れているといわれる ADSの安全性 について, 確率論的安全評価(PSA) 等 に基づく評価が紹介され，MA から生 成されるへリウムが事故時に放出され た場合の炬心特性への影響等が説明さ れた。

トピック 4 「技術と材料：核変換処 理に関連した特定の問題」では, 燃料 について，原研の小川より「核変換処 理専用燃料：窒化物および合金燃 料」, CEAの S. Pillon 氏より「核変換 処理専用燃料：酸化物燃料および夕ー ゲット燃料」と題した講義が行われ， MA 核変換処理のための専用然料の開 発の歴史, 物理的・化学的特性, 最新 の実験情報が幅広くカバーされた。続 いて, ADSの泠却材の有力候補であ る $\mathrm{Pb}-\mathrm{Bi}$ 合金について, FZK (独)の G. Schumacher 氏より「鉛合金：物理化 学的性質とADSへの応用に関する問 題 点」, ENEA(伊)の G. Benemati 氏 より「原子炬における $\mathrm{Pb}-\mathrm{Bi}$ 合金利 用：物理特性と互換性」と題した講義 が行われ, LECORループ実験の紹 介, 構造材と $\mathrm{Pb}-\mathrm{Bi}$ 合金との相互作
用の原理と対策が説明された。

構造材については, CEAの J.-L. Boutard 氏より「ADSターゲット構造 材の選択，照射特性」と題した講義が 行われ，T 91，EM 10等のマルテンサ イト系構造材に関する実験結果が紹介 された。再処理関連では, ANLのJ. Laidler 氏より「燃料再処理：湿式およ び乾式再処理技術」と題した講義が行 われ，米国の P\&T 政策の概要, 様々 な燃料形態と最適な再処理方法につい て, 特に乾式再処理の詳細が紹介され た。

トピック $5\lceil$ 「核データ」では, CEA のS. Leray氏より「高エネルギー核 データ：レビュー」，NRG Petten(オ ランダ)の A. Koning 氏より「0〜200 $\mathrm{MeV}$ における核データ」, CERN の P. Cennini 氏より「CERN·n_TOF 実験 : 設備の概要」と題した講義が行われ た。Leray, Koning両氏は，核デー 夕に関する理論・実験面での進展の紹 介に加え, ADSの核設計で広く使わ れている計算コードMCNPX を例に とり, 核モデルオプションの違い, 断 面積セットを用いた計算結果との比較 を通じて，ややもすればブラックボッ クス的な使われ方をしている計算コー ドの扱いに対する注意を喚起した。

また，特別講義として，CEAの J. Bouchard 氏より「将来型原子炉と燃 料サイクル：経験に基づく新しい展 望」と題し, 世界のエネルギー情勢, 放射性廃棄物の P\&T に関わる情勢を 背景として, Gen-IVの概要と, 検討 されている炉概念の各論に関する講義 が行われた。

以上の講義に加え, カダラッシュ研 究所内の燃料研究施設である LECA およびSTARの見学が行われた。

1 日のレクチャー終了後にはラップ アップセッションが設けられ，その日 の講義内容に関する自由討論, 意見交 換が行われた。特に，第 2 回目のラッ プアップセッションでは，中国原子能 研究院の夏海鴻氏より, 中国における ADS 関連研究が報告され, 聴衆の興 味を引いていた。
本セミナーでの生活など

本セミナーでは，1コマ 1 時間の講 義が午前, 午後に各 3 コマ, その後に ラップアップセッションが 1 コマ, と いうハードスケジュールが組まれてい た。その間，昼休みに 2 時間半，講義 終了後は 1 時間の休憩の後に, 夕食が 2 時間確保されているところはさすが フランスである。

シャトーでの食事はグルメ王国フラ ンスの名に恥じない充実したもので あった。 1 週目の火曜の夜は, マルセ イユの旧港を見下ろすレストランにて ディナー, 最終日前夜はシャトーで特 別ディナーが催され, 主催者側のもて なしのすばらしさを実感した。

週末プログラムも充実しており，土 曜日はマルセイユまたはエクサンプロ ヴァンス 1 日フリー観光, 日曜日には アルピーユ地方のバスッアーが企画さ れ，短いながらも南仏の夏を満喫する ことができた。

\section{おわりに}

最も印象深かったことは，ヨーロッ パでは, ADSによるP\&Tという方 向のもとに幅広い分野で極めて精力的 な研究活動が行われていることと，そ のことに魅せられた多くの若手研究 者, 博士課程学生が本セミナーに集っ ていたことである。全ヨーロッパとし てADSに取り組んでおり, 高速炉と 大型加速器, 両方の技術を有するヨー ロッパの底力を目の当たりにした，と いう感じである。

10日間という長丁場にわたり，講義 はもちろん，寝食をともにすることに よって自然とコミュニケーションの輪 が広がっていたのは，特に若手の参加 者にとってはかけがえのない財産とな ろう。主催者側からも要望があった が, 今後, 本セミナーへの日本からの 参加者が増えることを期待したい。と にかくハードではあるが, その分, 得 るものも大きいことは確かである。

(2002年 12 月 3 日 記) 